\title{
Late diagnosis of Human Immunodeficiency Virus infection and associated factors*
}

\author{
Luana Carla Santana Ribeiro ${ }^{1}$ \\ (i) https://orcid.org/0000-0003-3485-3100 \\ Maria Imaculada de Fátima Freitas ${ }^{2}$ \\ (D) https://orcid.org/0000-0002-0273-9066 \\ Unaí Tupinambás ${ }^{3}$ \\ (1) https://orcid.org/0000-0001-6833-3870 \\ Francisco Carlos Félix Lana ${ }^{2}$ \\ (D) https://orcid.org/0000-0001-9043-3181
}

Objective: to analyze the occurrence of late diagnosis of infection by the Human Immunodeficiency Virus and its associated factors. Method: this is an epidemiological, crosssectional and analytical study, carried out with 369 people followed-up by Specialized Assistance Services, undergoing anti-retroviral treatment, and interviewed by means of a questionnaire. Univariate analysis was performed using Pearson's chi-square test or Fisher's exact test and KruskallWallis test, and multivariate analysis using the ordinal logistic regression model of proportional odds. Results: the occurrence of $59.1 \%$ for late diagnosis of the infection was observed; the probability of later diagnosis is greater among people who have a steady partnership, when compared to those who do not; with increasing age, particularly above 35 years old; among those with lower schooling; for those who seek the health services to have an HIV test when they feel sick; and for those who test HIV less often or never do it after sex without a condom with a steady partner. Conclusion: the knowledge on the high proportion of late diagnosis and its associated factors verified in this study make the planning and implementation of new policies and strategies aimed at the timely diagnosis of the infection imperative.

Descriptors: HIV; Acquired Immunodeficiency Syndrome; HIV Infections; Delayed Diagnosis; Early Diagnosis; CrossSectional Studies.

\section{How to cite this article}

Ribeiro LCS, Freitas MIF, Tupinambás U, Lana FCF. Late diagnosis of Human Immunodeficiency Virus infection and associated factors. Rev. Latino-Am. Enfermagem. 2020;28:e3342. [Access $f$ \& 1 ]; Available in: DOI: http://dx.doi.org/10.1590/1518-8345.4072.3342. 


\section{Introduction}

Since the beginning of the Human Immunodeficiency Virus (HIV) infection pandemic in the 1980s, Brazil has implemented a series of government and social measures to tackle the epidemic. In the last few decades, a significant decrease in AIDS morbidity and mortality has been observed in the country, due to the introduction of universal and free access to antiretroviral therapy (ART), the harm reduction policy, the implementation of combined prevention strategies, the recommendation of treatment as prevention, and the wide range of diagnostic tests ${ }^{(1-3)}$. These strategies have jointly contributed to the increase in the life expectancy and quality of life of people living with HIV (PLHIV), to the decrease in hospital admissions due to the reduction of opportunistic infections, and to the reduction of HIV transmission ${ }^{(4-6)}$.

Despite the efforts and integrated actions of the governments, of civil society, of social movements, and of non-governmental organizations in tackling the AIDS epidemic, the tendency for its morbidity and mortality to decline, the expanded access to ART, and the technological advances in case management, this condition remains at the top of public health problems, affecting the population's quality of life and impacting the economy and the social and family structures ${ }^{(7-8)}$.

The delay in the diagnosis and the consequent late assistance to PLHIV are some of the main concerns in combating the epidemic ${ }^{(7,9)}$. The early diagnosis, together with the immediate initiation of the treatment, brings irrefutable health benefits to PLHIV, due to its greater effectiveness in maintaining the immune status and reducing morbidity and mortality. It also contributes to its prevention, since the spread of the infection is avoided in a phase marked by high viral loads and high infectious potential, which also results in greater investment of time and resources by the health systems ${ }^{(10-12)}$.

Clinical and laboratory monitoring of HIV infection is performed by counting CD4+T lymphocytes (LT$\mathrm{CD} 4+$ ) and viral load (VL). According to data from the Ministry of Health (MoH), in 2018 27\% of PLHIV arrived at the health service with an HIV infection late diagnosis (LD), considering the CD4 count criterion below 200 cells $/ \mathrm{mm}^{3(13)}$.

A research study carried out in Brazil, which used the criterion of late onset of clinical follow-up for asymptomatic patients with an LT-CD4+ count below 350 cells $/ \mathrm{mm}^{3}$, in the 2003-2006 period, revealed that the prevalence of late onset was $58.6 \%$, resulting in an increase of more than a third in the AIDS mortality rates. Another relevant conclusion of the study was that if all patients had started treatment in a timely manner, the decrease in AIDS mortality could have been $62.5 \%$ (against the $43.0 \%$ observed), between 1995 and 2006 , increasing by $45.2 \%{ }^{(14)}$ the effectiveness of the program to deal with this epidemic.

The prevalence of late diagnosis of HIV infection was also estimated in other countries, such as the United States, Australia, France, Italy, and Canada, which presented proportions of this event that varied from $8.8 \%$ in Canada, to $28.7 \%$ in the United States, considering as one of the criteria a CD4 count below 200 cells $/ \mathrm{mm}^{3(12)}$. A research study involving 30,454 individuals, from 34 European countries, estimated the prevalence of late onset (which can express late diagnosis or late entry to care), in the period from 2010 to 2013 , at $47.9 \%$, using the as a parameter a CD4 count below 350 cells $/ \mathrm{mm}^{3}$ or an AIDS diagnosis within 6 months after HIV diagnosis ${ }^{(15)}$.

Timely diagnosis of HIV infection and prompt care for diagnosed people are an important part of the strategies in most countries. It is noteworthy that PLHIV using ART, which maintain LT-CD4+ counts above 500 cells $/ \mathrm{mm}^{3}$ and undetectable VLs, reach a level of life expectancy similar to that of the general population ${ }^{(16)}$.

In Brazil, despite efforts to control the HIV epidemic, they are focused on the early diagnosis of the infection, on the treatment of PLHIV, and on the implementation of combined prevention interventions ${ }^{(17)}$ and, despite the high rates of late diagnosis, there is a scarcity of studies on this issue which address its quantitative dimension, such as the occurrence of late diagnosis according to current parameters and associated factors.

Thus, the objective of this study was to analyze the occurrence of late diagnosis of infection by the Human Immunodeficiency Virus and its associated factors.

\section{Method}

This is an excerpt from the quantitative axis of a research with a mixed approach, carried out in the state of Paraíba, in the Northeast of Brazil. It is an epidemiological, cross-sectional and analytical study that included the six Specialized Assistance Services (SASs) of the state, in activity in 2017.

The population consisted of all the adults living with HIV on ART, followed-up by the referred SASs. The sample was of the stratified probabilistic type and the following inclusion criteria were considered: PLHIV on 
ART, over 18 years of age and in outpatient follow-up at the SASs. The exclusion criteria were the following: people with HIV hospitalized during the data collection period; and those with some neurological or cognitive disability that made it impossible for them to participate in the interview.

To perform the sample calculation, the $95 \%$ confidence interval (CI) was considered, the proportion of late diagnosis was $60 \%(18-19)$, the maximum allowed error was $5 \%$ and the probability of sample loss was $10 \%$, resulting in a sample of 369 people with HIV. As the sampling was stratified, the sample calculation was performed for each stratum, that is, for each SAS, proportionally to the population.

For data collection, a questionnaire was used designed for research purposes, applied with a faceto-face interview, containing dichotomous, categorical, and Likert scale questions. Data collection was carried out from April to May 2017, using primary sources of research - interviews with PLHIV followed-up in the SASs and data from medical records to avoid memory bias. The medical records were consulted to obtain the LT-CD4+ count and viral load at the time of diagnosis, the date of diagnosis of HIV infection, the date on which ART was started, and the presence of AIDS-indicative disease at the time of diagnosis.

In order to ensure the minimum sample size in the period of one month of data collection and to select the research participants, a probabilistic draw of the days for the collection in each SAS was carried out. The number of days to be drawn in each service was obtained by the ratio between the minimum sample size calculated for each SAS and the mean daily attendance for dispensing anti-retroviral drugs in each service. An additional day (backup) was drawn for collection in each service, assuming the occurrence of unforeseen events or difficulties in the dynamics of the services' operation. Thus, single-stage cluster sampling, stratified by the health service, was used for the draw procedure, with the day being the primary sampling unit and the strata designed by the establishments.

During data collection, the planning of the days drawn was not carried out exactly, due to the service logistics in the services, which on some dates did not allow access to interview users. These days were replaced by other dates that made it possible to reach the sample size previously established. In addition, there was approximately $15 \%$ of refusals to participate in the study, a fact already expected due to the fear of the stigma experienced by many PLHIV. However, it is noteworthy that the interviews were conducted in places that guaranteed the privacy of the participants, which favored people's adherence to participate in the study, reaching the calculated sample.

Regarding the variables used in the study, the time of diagnosis was considered as the outcome, obtained by the LT-CD4+ count proxy variable at the time of diagnosis ${ }^{(10,12,14,19)}$. This response variable was categorized as follows: timely diagnosis, characterized by an LT-CD4+ count equal to or greater than 350 cells $/ \mathrm{mm}^{3}$; late diagnosis, defined by LT$\mathrm{CD}+$ count equal to or greater than 200 cells $/ \mathrm{mm}^{3}$ and below 350 cells $/ \mathrm{mm}^{3}$; and very late diagnosis, measured by LT-CD4+ count below 200 cells $/ \mathrm{mm}^{3}$ or characteristic AIDS disease in the initial exam, regardless of the LT-CD4+ count. The exposure variables used in the study included sociodemographic variables, related to access to HIV diagnosis and to the sexuality of PLHIV.

Data was stored and analyzed in the SPSS software, version 21.0. First, the proportions of the timely, late, and very late diagnosis of HIV infection were estimated, based on the LT-CD4+ count proxy variable at the diagnosis time.

In the univariate analysis to assess the factors associated with the diagnosis, classified as very late, late, and timely, the Pearson's chi-square or Fisher's exact tests were used in the analysis of categorical variables, and the Kruskall-Wallis test in the analysis of the numerical variables. All the numerical variables showed an asymmetric distribution, according to the Kolmogorov-Smirnov normality test.

In the multivariate analysis, to assess the factors associated with late diagnosis, as it is an ordinal categorical outcome (very late, late and timely diagnosis), the ordinal logistic regression model of proportional odds was used(20). In this study, the Odds Ratio (OR) represents the chance of a patient having a later diagnosis.

During the modeling process, all the variables with a p-value below 0.20 , according to the univariate analysis, were included in the multivariate model. The model was produced in blocks, according to the classification of the groups of variables: Block 1 Sociodemographic factors; Block 2 - Factors related to access to the services; Block 3 - Factors related to sexuality. The model performed in each block used the backward method to remove the variables and only variables with a significance level equal to or less than $5 \%$ remained. Then, the variables that remained in the final model of each block were included in a single model 
simultaneously and the backward modeling process was performed again, with only the significant variables remaining at the $5 \%$ level.

After adjusting the final model, the OR values were estimated, with respective $95 \%$ confidence intervals ( $95 \% \mathrm{CIs}$ ). It should be noted that the final model presented a good fit, according to the Deviance statistic ( $p$-value $=0.955$ ), and the assumption of parallel lines proved to be valid ( $p$-value $=0.590$ ).

In all the analyses, the confidence intervals had a $95 \%$ confidence level and the $p$-value $<0.05$ decided to reject the null hypothesis in the statistical tests used in this work. Finally, the results found in line with the relevant literature were discussed.

In compliance with CNS Resolution No. 466/2012, the research was submitted to the appreciation of Research Ethics Committees, through Plataforma Brasil, and approved with the following Opinion numbers: 1,870,281 (UFMG), 1,932,530 (UFPB - HULW), and $1,973,626$ (UFCG - HUAC).

\section{Results}

Most of the study participants were male (cisgender men) $(55.0 \%)$ and were in adulthood, and aged 25 to 49 years old $(68.3 \%)$ at the time they were diagnosed with HIV. However, the percentage of HIVpositive young people aged up to 24 years old is noteworthy, which corresponded to $20.4 \%$ of the respondents. As for race or skin color, 257 (69.6\%) of the survey participants declared themselves to be brown $(55.0 \%)$ or black $(14.6 \%)$. At the time of diagnosis, most of the respondents were married or in a stable relationship (50.9\%) and had a low level of schooling (52.0\%).

Regarding the "time of diagnosis" outcome, it was evidenced that $59,1 \%$ of the total of the interviewees were late diagnosed $(18.2 \%$ with a $\mathrm{T}$ CD4+ lymphocyte count of $200-349$ cells $/ \mathrm{mm}^{3}$ ) or very late diagnosed (40.9\% with a T CD4+ lymphocyte count below 200 cells $/ \mathrm{mm}^{3}$ ), and $37.4 \%$ of them received the diagnosis in a timely manner, with an LT-CD4+ value corresponding to 350 cells $/ \mathrm{mm}^{3}$ or more. At the time of diagnosis, the mean and median LT-CD4+ values of the research participants were 313.29 cells/ $\mathrm{mm}^{3}$ and 253 cells $/ \mathrm{mm}^{3}$, respectively. The lowest LTCD4+ count recorded at the time of diagnosis was equal to 2 cells $/ \mathrm{mm}^{3}$ and the highest count was 1,743 cells $/ \mathrm{mm}^{3}$.
The results also showed that $238(64.5 \%)$ of the total participants had a high VL at the time of diagnosis, with values above 10,000 copies/ml.

Table 1, based on univariate analysis, shows sociodemographic variables and their association with the diagnosis of HIV infection, classified as very late, late, and timely.

Among the sociodemographic factors, there was an association with the diagnosis of HIV infection ( $p$-value < 0.05): pregnancy when the infection was discovered, age, marital status, religion, and schooling. It appears that women in general were diagnosed later than pregnant women. The pregnancy variable was not included in the multivariate analysis as it is a condition that applies only to women of childbearing age and not to the general population investigated in the study.

Regarding age, the longer the life span, the later the diagnosis took place. The mean age of the participants who were diagnosed very late was 37.6 years and, of those diagnosed late, 35.9 years old.

People with a steady partnership were diagnosed later, as were those of the Catholic religion. In addition, it was shown that the lower the schooling level (in years of study), the later the diagnosis.

Table 2 shows the factors related to access to the health services and their association with HIV infection diagnosis.

The only variable that was statistically associated with a late diagnosis of HIV infection in relation to access to the health services, in the univariate analysis ( $p$-value $<0.05$ ), was the reason why they sought the health service to perform the HIV test ( $p$-value $<0.001)$. It was verified that the diagnosis was later among those who sought the service because they felt sick.

Table 3 shows the variables related to the sexuality of the interviewed PLHIV that were associated with HIV infection diagnosis, in the univariate analysis.

It was observed that the diagnosis was later among those who never tried to do the quick test after intercourse without a condom with a steady partner and who reported being ashamed to suggest the use of condoms to their partner ( $p$-value $<0.05$ ).

In the multivariate analysis, considering all the variables that remained in the final models of each block in a single model, the variables shown in Table 4 remained in the final model. 
Table 1 - Sociodemographic factors and association with HIV infection diagnosis. Paraíba, PB, Brazil, 2017 ( $\mathrm{n}=356)$

\begin{tabular}{|c|c|c|c|c|}
\hline \multirow{2}{*}{ Variable } & \multicolumn{3}{|c|}{ Diagnosis } & \multirow{2}{*}{$p$-value } \\
\hline & Very late $(n=151)$ & Late $(n=67)$ & Timely $(n=138)$ & \\
\hline \multicolumn{5}{|l|}{ Gender } \\
\hline Female & $58(37.6 \%)$ & $30(19.5 \%)$ & $66(42.9 \%)$ & $0.364^{*}$ \\
\hline Male & $91(46.9 \%)$ & $34(17.5 \%)$ & $69(35.6 \%)$ & \\
\hline Trans-sexual/Transvestite & $2(28.6 \%)$ & $2(28.6 \%)$ & $3(42.8 \%)$ & \\
\hline \multicolumn{5}{|l|}{ Pregnancy } \\
\hline Yes & $6(13.6 \%)$ & $11(25.0 \%)$ & $27(61.4 \%)$ & $<0.001^{\dagger}$ \\
\hline No & $49(47.5 \%)$ & $18(17.5 \%)$ & $36(35.0 \%)$ & \\
\hline \multicolumn{5}{|l|}{ Age in years old } \\
\hline Mean \pm Standard Deviation & $37.6 \pm 10.9$ & $35.9 \pm 11.4$ & $30.6 \pm 10.9$ & $<0.001^{\ddagger}$ \\
\hline Median (minimum - maximum) & $37(3-63)$ & $35(19-66)$ & $28.5(1-74)$ & \\
\hline \multicolumn{5}{|l|}{ Ethnicity } \\
\hline White & $49(49.0 \%)$ & $16(16.0 \%)$ & $35(35.0 \%)$ & $0.219^{*}$ \\
\hline Black & $16(29.6 \%)$ & $14(25.9 \%)$ & $24(44.5 \%)$ & \\
\hline Brown & $84(43.3 \%)$ & $36(18.6 \%)$ & $74(38.1 \%)$ & \\
\hline Others & $1(16.7 \%$ & $1(16.7 \%)$ & $4(66.6 \%)$ & \\
\hline \multicolumn{5}{|l|}{ Marital status } \\
\hline No stcady partner & $67(39.0 \%)$ & $27(15.7 \%)$ & $78(45.3 \%)$ & $0.042^{+}$ \\
\hline With steady partner & $84(45.7 \%)$ & $40(21.7 \%)$ & $60(32.6 \%)$ & \\
\hline \multicolumn{5}{|l|}{ Religion } \\
\hline No religion & $23(33.3 \%)$ & $19(27.6 \%)$ & $27(39.1 \%)$ & $0.037^{*}$ \\
\hline Catholic & $93(47.9 \%)$ & $34(17.6 \%)$ & $67(34.5 \%)$ & \\
\hline Evangelic & $30(40.5 \%)$ & $13(17.6 \%)$ & $31(41.9 \%)$ & \\
\hline Others & $5(26.3 \%)$ & $1(5.3 \%)$ & $13(68.4 \%)$ & \\
\hline \multicolumn{5}{|l|}{ Escholing in years } \\
\hline Mean \pm Standard Deviation & $7.4 \pm 4.3$ & $7.9 \pm 4.3$ & $9.5 \pm 4.6$ & $<0.001^{\ddagger}$ \\
\hline Median (minimum - maximum) & $6(0-20)$ & $7(0-20)$ & $11(0-23)$ & \\
\hline \multicolumn{5}{|l|}{ Affective sexual orientation } \\
\hline Heterosexual & $109(43.3 \%)$ & $50(19.8 \%)$ & $93(36.9 \%)$ & $0.769^{*}$ \\
\hline Homosexual & $31(39.7 \%)$ & $12(15.4 \%)$ & $35(44.9 \%)$ & \\
\hline Bisexual & $11(44.0 \%)$ & $5(20.0 \%)$ & $9(36.0 \%)$ & \\
\hline
\end{tabular}

Table 2 - Factors related to access to the services and association with the diagnosis of HIV infection. Paraíba, PB, Brazil, $2017(n=356)$

\begin{tabular}{|c|c|c|c|c|}
\hline \multirow[b]{2}{*}{ Variable } & \multicolumn{3}{|c|}{ Diagnosis } & \multirow[b]{2}{*}{ p-value } \\
\hline & $\begin{array}{l}\text { Very late } \\
(n=151)\end{array}$ & $\begin{array}{c}\text { Late } \\
(n=67)\end{array}$ & $\begin{array}{c}\text { Timely } \\
(\mathrm{n}=138)\end{array}$ & \\
\hline \multicolumn{5}{|l|}{ Motivation of the person to seek the health service to perform the test HIV } \\
\hline Medical or prenatal indication & $47(35.3 \%)$ & $31(23.3 \%)$ & $55(41.4 \%)$ & $<0.001^{*}$ \\
\hline For feeling sick & $77(73.4 \%)$ & $14(13.3 \%)$ & $14(13.3 \%)$ & \\
\hline After sexual intercourse with a positive HIV partner or to know their serological status & $23(23.7 \%)$ & $17(17.5 \%)$ & $57(58.8 \%)$ & \\
\hline After an unprotected relationship, blood donation, illnes of spouse or others & $4(19.1 \%)$ & $5(23.8 \%)$ & $12(57.1 \%)$ & \\
\hline \multicolumn{5}{|l|}{ First health service sought for HIV testing } \\
\hline $\mathrm{BHU} / \mathrm{FHU}$ & $24(32.0 \%)$ & $19(25.3 \%)$ & $32(42.7 \%)$ & $0.177^{*}$ \\
\hline Reference clinic, SAS or TCC & $30(41.6 \%)$ & $11(15.3 \%)$ & $31(43.1 \%)$ & \\
\hline Public or Private Hospital & $66(50.7 \%)$ & $21(16.2 \%)$ & $43(33.1 \%)$ & \\
\hline Private practice clinic, first-aid service or others & $30(38.5 \%)$ & $16(20.5 \%)$ & $32(41.0 \%)$ & \\
\hline \multicolumn{5}{|l|}{ Time to receive the result } \\
\hline Same day & $72(41.6 \%)$ & $28(16.2 \%)$ & $73(42.2 \%)$ & $0.070^{*}$ \\
\hline Less than a week & $35(54.6 \%)$ & $9(14.1 \%)$ & $20(31.3 \%)$ & \\
\hline More than a week & $44(37.3 \%)$ & $30(25.4 \%)$ & $44(37.3 \%)$ & \\
\hline
\end{tabular}


Table 2 - (continuation)

\begin{tabular}{|c|c|c|c|c|}
\hline \multirow[b]{2}{*}{ Variable } & \multicolumn{3}{|c|}{ Diagnosis } & \multirow[b]{2}{*}{ p-value } \\
\hline & $\begin{array}{l}\text { Very late } \\
(\mathrm{n}=151)\end{array}$ & $\begin{array}{c}\text { Late } \\
(\mathrm{n}=67)\end{array}$ & $\begin{array}{l}\text { Timely } \\
(n=138)\end{array}$ & \\
\hline \multicolumn{5}{|c|}{ Times they needed to go to the health service to find out that they had HIVIAIDS } \\
\hline Mean \pm Standard Deviation & $1.8 \pm 2.5$ & $2.6 \pm 5.4$ & $1.8 \pm 2.1$ & $0.088^{\dagger}$ \\
\hline Median (minimum - maximum) & $1(1-20)$ & $1(1-44)$ & $1(1-22)$ & \\
\hline \multicolumn{5}{|l|}{ Health service that made the diagnosis } \\
\hline $\mathrm{BHU} / \mathrm{FHU}$ & $18(32.7 \%)$ & $15(27.3 \%)$ & $22(40.0 \%)$ & $0.100^{*}$ \\
\hline Reference clinic, SAS or TCC & $35(35.7 \%)$ & $20(20.4 \%)$ & $43(43.9 \%)$ & \\
\hline Public or Private Hospital & $75(51.3 \%)$ & $22(15.1 \%)$ & $49(33.6 \%)$ & \\
\hline Private clinic, first-aid service, LAB. $P$ or others & $22(40.0 \%)$ & $9(16.4 \%)$ & $24(43.6 \%)$ & \\
\hline \multicolumn{5}{|l|}{ Distance from the house to the job place } \\
\hline Too far/Far away & $86(44.1 \%)$ & $40(20.5 \%)$ & $69(35.4 \%)$ & $0.136^{*}$ \\
\hline Regular & $25(49.0 \%)$ & $4(7.9 \%)$ & $22(43.1 \%)$ & \\
\hline Near/Very near & $39(35.8 \%)$ & $23(21.1 \%)$ & $47(43.1 \%)$ & \\
\hline \multicolumn{5}{|l|}{ Means of transportation used } \\
\hline Oublic transportation & $76(39.6 \%)$ & $30(15.6 \%)$ & $86(44.8 \%)$ & $0.094^{*}$ \\
\hline Own car/motorcycle & $33(45.8 \%)$ & $14(19.5 \%)$ & $25(34.7 \%)$ & \\
\hline Others & $42(45.7 \%)$ & $23(25.0 \%)$ & $27(29.3 \%)$ & \\
\hline
\end{tabular}

${ }^{*}$ Chi-square test; ${ }^{+}$Kruskal Wallis.

Table 3 - Factors related to sexuality and association with HIV infection diagnosis. Paraíba, PB, Brazil, 2017 ( $\mathrm{n}=356)$

\begin{tabular}{|c|c|c|c|c|}
\hline \multirow{2}{*}{ Variable } & \multicolumn{3}{|c|}{ Diagnosis } & \multirow{2}{*}{ p-value } \\
\hline & Very late $(n=151)$ & Late $(n=67)$ & Timely $(n=138)$ & \\
\hline \multicolumn{5}{|l|}{$\begin{array}{l}\text { Age when they had sex for the } \\
\text { first time }\end{array}$} \\
\hline Mean \pm Standard Deviation & $17 \pm 4.7$ & $15.9 \pm 2.8$ & $16.1 \pm 3.8$ & $0.348^{*}$ \\
\hline Median (minimum - maximum) & $16(9-47)$ & $16(8-22)$ & $16(8-36)$ & \\
\hline \multicolumn{5}{|l|}{ Used condom in the first intercourse } \\
\hline Yes & $35(36.5 \%)$ & $17(17.7 \%)$ & $44(45.8 \%)$ & $0.256^{\dagger}$ \\
\hline No & $114(44.2 \%)$ & $50(19.4 \%)$ & $94(36.4 \%)$ & \\
\hline \multicolumn{5}{|c|}{ Number of partners with whom they have already had sex } \\
\hline Up to 9 & $75(37.1 \%)$ & $41(20.3 \%)$ & $86(42.6 \%)$ & $0.083^{\dagger}$ \\
\hline 10 or more & $73(49.0 \%)$ & $24(16.1 \%)$ & $52(34.9 \%)$ & \\
\hline \multicolumn{5}{|l|}{ Frequency using the condom } \\
\hline Always or almost always & $66(43.7 \%)$ & $24(15.9 \%)$ & $61(40.4 \%)$ & $0.736^{+}$ \\
\hline Sometimes & $34(39.5 \%)$ & $20(23.3 \%)$ & $32(37.2 \%)$ & \\
\hline Never or almost never & $51(42.9 \%)$ & $23(19.3 \%)$ & $45(37.8 \%)$ & \\
\hline \multicolumn{5}{|c|}{$\begin{array}{l}\text { Frequency of performing the quick HIV test (after an } \\
\text { unprotected relationship with a steady partner) }\end{array}$} \\
\hline Always or almost always & $4(17.4 \%)$ & $3(13.0 \%)$ & $16(69.6 \%)$ & $0.028^{\ddagger}$ \\
\hline Sometimes & $3(37.5 \%)$ & $2(25.0 \%)$ & $3(37.5 \%)$ & \\
\hline Never or almost never & $144(44.3 \%)$ & $62(19.1 \%)$ & $119(36.6 \%)$ & \\
\hline \multicolumn{5}{|c|}{$\begin{array}{l}\text { Frequency of quick HIV testing (after an unprotected } \\
\text { intercourse with a casual partner) }\end{array}$} \\
\hline Always or almost always & $6(33.3 \%)$ & $2(11.1 \%)$ & $10(55.6 \%)$ & $0.367^{\ddagger}$ \\
\hline Sometimes & $4(36.4 \%)$ & $4(36.4 \%)$ & $3(27.2 \%)$ & \\
\hline Never or almost never & $141(43.1 \%)$ & $61(18.7 \%)$ & $125(38.2 \%)$ & \\
\hline \multicolumn{5}{|c|}{$\begin{array}{l}\text { Reasons that influenced for not using condoms } \\
\text { Trusting the partner }\end{array}$} \\
\hline Yes & $120(41.5 \%)$ & $52(18.0 \%)$ & $117(40.5 \%)$ & $0.371^{\dagger}$ \\
\hline No & $31(46.3 \%)$ & $15(22.4 \%)$ & $21(31.3 \%)$ & \\
\hline
\end{tabular}


Table 3 - (continuation)

\begin{tabular}{|c|c|c|c|c|}
\hline \multirow{2}{*}{ Variable } & \multicolumn{3}{|c|}{ Diagnosis } & \multirow{2}{*}{$\mathrm{p}$-value } \\
\hline & Very late $(n=151)$ & Late $(n=67)$ & Timely $(n=138)$ & \\
\hline \multicolumn{5}{|l|}{ Having a steady partner } \\
\hline Yes & $107(42.3 \%)$ & $45(17.8 \%)$ & $101(39.9 \%)$ & $0.659^{\dagger}$ \\
\hline No & $44(42.7 \%)$ & $22(21.4 \%)$ & $37(35.9 \%)$ & \\
\hline \multicolumn{5}{|l|}{ Long-lasting relationship } \\
\hline Yes & $107(41.0 \%)$ & $52(19.9 \%)$ & $102(39.1 \%)$ & $0.560^{\dagger}$ \\
\hline No & $44(46.3 \%)$ & $15(15.8 \%)$ & $36(37.9 \%)$ & \\
\hline \multicolumn{5}{|l|}{ Religious reasons } \\
\hline Yes & $14(35.0 \%)$ & $5(12.5 \%)$ & $21(52.5 \%)$ & $0.161^{\dagger}$ \\
\hline No & $137(43.4 \%)$ & $62(19.6 \%)$ & $117(37.0 \%)$ & \\
\hline \multicolumn{5}{|l|}{ Decreases or takes away pleasure } \\
\hline Yes & $67(38.7 \%)$ & $40(23.1 \%)$ & $66(38.2 \%)$ & $0.112^{\dagger}$ \\
\hline No & $84(45.9 \%)$ & $27(14.8 \%)$ & $72(39.3 \%)$ & \\
\hline \multicolumn{5}{|l|}{ Partner refuses to use } \\
\hline Yes & $63(39.6 \%)$ & 30 (18.9\%) & $66(41.5 \%)$ & $0.588^{\dagger}$ \\
\hline No & $88(44.7 \%)$ & $37(18.8 \%)$ & $72(36.5 \%)$ & \\
\hline \multicolumn{5}{|l|}{ Dislikes using it } \\
\hline Yes & $63(43.2 \%)$ & $25(17.1 \%)$ & $58(39.7 \%)$ & $0.812^{\dagger}$ \\
\hline No & $88(41.9 \%)$ & $42(20.0 \%)$ & $80(38.1 \%)$ & \\
\hline \multicolumn{5}{|c|}{ Ashamed of suggesting its use to the partner } \\
\hline Yes & $23(65.7 \%)$ & $3(8.6 \%)$ & $9(25.7 \%)$ & $0.012^{\dagger}$ \\
\hline No & $128(39.9 \%)$ & $64(19.9 \%)$ & $129(40.2 \%)$ & \\
\hline \multicolumn{5}{|l|}{ Not being able to buy } \\
\hline Yes & $7(41.2 \%)$ & $5(29.4 \%)$ & $5(29.4 \%)$ & $0.492^{\ddagger}$ \\
\hline No & $144(42.5 \%)$ & $62(18.3 \%)$ & $133(39.2 \%)$ & \\
\hline \multicolumn{5}{|l|}{ Others } \\
\hline Yes & $3(30.0 \%)$ & $2(20.0 \%)$ & $5(50.0 \%)$ & $0.700^{\ddagger}$ \\
\hline No & $148(42 ., 8 \%)$ & 65 (18.8\%) & $133(38.4 \%)$ & \\
\hline
\end{tabular}

Table 4 - Final model, according to ordinal logistic regression of proportional chances, for the assessment of the factors associated with HIV infection late diagnosis. Paraíba, PB, Brasil, 2017 ( $n=356)$

\begin{tabular}{|c|c|c|c|c|}
\hline \multirow[b]{2}{*}{ Age (years old) } & \multirow{2}{*}{$\frac{\text { OR* }^{*}}{1.03}$} & \multicolumn{2}{|c|}{$95 \% \mathrm{IC}^{\dagger}$} & \multirow{2}{*}{$\frac{\text { p-value }}{0.001}$} \\
\hline & & 1.01 & 1.06 & \\
\hline \multicolumn{5}{|l|}{ Marital status } \\
\hline No steady partner & 1.00 & - & - & - \\
\hline With steady partner & 1.58 & 1.01 & 2.46 & 0.045 \\
\hline Schooling (years) & 0.94 & 0.89 & 0.99 & 0.016 \\
\hline \multicolumn{5}{|l|}{ Motivation of the person to seek the health service to perform the HIV test } \\
\hline Medical or prenatal indication & 1.00 & - & - & - \\
\hline Feeling sick & 4.92 & 2.80 & 8.64 & $<0.001$ \\
\hline After sexual intercourse with an HIV positive partner or to know their HIV status & 0.60 & 0.35 & 1.02 & 0.060 \\
\hline After an unprotected relationship, blood donation, illness of spouse or others & 0.52 & 0.20 & 1.34 & 0.176 \\
\hline \multicolumn{5}{|c|}{ Frequency of quick HIV testing (after an unprotected intercourse with a steady partner) } \\
\hline Always or almost always & 1.00 & - & - & - \\
\hline Sometimes & 3.33 & 1.26 & 8.84 & 0.016 \\
\hline Never or almost never & 6.40 & 1.23 & 33.25 & 0.027 \\
\hline
\end{tabular}

*OR - Odds Ratio; ${ }^{+95 \%}$ CI - 95\% Confidence Interval; Deviance Statistics p-value $=0.955$; Parallel Lines Test $p$-value $=0.590$ 
According to these results, the following factors ( $p$-values $<0.05$ ), associated with HIV infection late diagnosis, remained in the final model: age, marital status, schooling, reason for which they sought the health service to perform the HIV test, and frequency of the quick HIV test after an unprotected relationship with a steady partner.

The results of the model indicate that, with the increase of one year old in age, the chance of a later diagnosis increases 1.03 times (or $3 \%$ ), and can vary between 1.01 and 1.06 with $95 \%$ confidence. People with a steady affective partner have 1.58 times (or 58\%) more chances of a later diagnosis than those who do not have a steady partner $(95 \% \mathrm{CI}=1.01-2.46)$. The increase in schooling was associated with a lower chance of later diagnosis (OR $=0.94 ; 95 \%$ CI $=0.89-0.99$ ).

In addition, HIV-positive individuals who reported having sought the health service to perform the HIV test because they feel sick are 4.92 times more likely to be diagnosed later than those who sought the service by medical indication or due to the performance of prenatal care $(95 \% \mathrm{CI}=2.80-8.64)$.

Finally, the lower the frequency of quick HIV testing after unprotected sex with a steady partner, the greater the chance of a later diagnosis of the infection. Among those who never undergo screening, the chance of later diagnosis rises to 6.40 times ( $95 \% \mathrm{CI}=1.23-33.25$ ).

\section{Discussion}

The high occurrence of late or very late HIV infection diagnosis $(59.1 \%)$ found portrays an alarming reality, with higher data than the national ones, in which the percentage of $42 \%$ of people diagnosed with a lower LTCD4+ count was identified at 350 cells $/ \mathrm{mm}^{3}$ in $2015^{(18)}$.

However, the percentage of delayed diagnosis of HIV infection was similar to results found in other developing countries, such as China, which corresponded to $72.6 \%$ in the period from 2009 to $2010^{(9)}$, Ethiopia, with $68.8 \%$ of delayed diagnosis in $2014(21)$, and Mexico, with a late diagnosis prevalence of $49 \%$ in the period from 2008 to $2013^{(22)}$. However, these surveys used heterogeneous criteria to define a delay in the diagnosis or late onset, which non-standardizes the results and hinders the comparison among the countries.

In Brazil, research studies on late onset for the care with HIV infection published from 2011 to 2016 estimated prevalence rates ranging from $52.5 \%$ to $69.8 \%{ }^{(14,23-26)}$. These results are below what is expected for consolidated public health programs for PLHIV, such as that of Brazil(24).

Like Brazil, most of the countries in Latin America face a concentrated epidemic, with a large number of people still undiagnosed and a high prevalence of late diagnosis and, consequently, late onset of $\mathrm{ART}^{(27)}$. Late diagnosis is a continuous, worrying, and serious challenge for the control of the AIDS pandemic, as it is directly related to higher rates of morbidity and mortality ${ }^{(28-29)}$ and to the need for greater investment by the health systems ${ }^{(10,30)}$.

The gender variable was not a factor associated with late or very late diagnosis in this study, unlike other studies, which reported that men are more likely to have a LD of HIV infection or advanced disease when compared to women(15,31-32). However, it was evident in the univariate analysis that women in general were diagnosed later than pregnant women. An equivalent result was found in a survey conducted in the Northeast of Brazil, which found that the prevalence of late onset of HIV, between 2007 and 2009, was twice as high among men (55.4\%) and among women who did not become pregnant $(56.0 \%)$, when compared to the prevalence in pregnant women $(21.1 \%)^{(23)}$. Several studies have described similar percentages of LD among men and women, and it is relevant to consider pregnancy as a possible confounding variable, since the request for HIV testing is a prenatal routine and favors the timely diagnosis in pregnant women ${ }^{(12,23)}$.

As for the age variable, the longer the life span, the later the diagnosis. One of the aspects that may be related is the delay in carrying out HIV screening after unprotected sex, resulting in the discovery of the infection long after exposure to the virus and, thus, at an older age. A number of research studies indicate that older people are more likely to be diagnosed late, especially those aged 50 years old or older, which can be explained by the decreased risk perception and the subsequent reduction in the frequency of diagnostic tests in this group ${ }^{(25,29,32-34)}$.

Marital status is also a determining factor for LD. Being in a conjugal relationship can cause people to have an attitude of trust and a subsequent practice of sexual intercourse without a condom, due to the denial of the risk of becoming infected. Generally, the practice of protected sexual relations is limited to the beginning of the relationships and, as time goes by, the ability to negotiate condom use decreases, as does the "purification" of the partner, leading to abandoning the condom $^{(35)}$. This practice happens since the beginning of sexual life in adolescence ${ }^{(36)}$.

In a study conducted in Turkey, the late onset for HIV care measures was more likely among married patients, diagnosed between 2003 and 2016. We emphasize the relationship of these results with the low perception of risk or its denial in these groups and the consequent failure to carry out diagnostic tests, in addition to the fact 
that, since married people are apparently considered to have a reduced risk of being infected, the physicians do not usually prescribe HIV tests(37).

The main reasons for LD are the absence or low perception on the risk on the part of vulnerable people $^{(38-39)}$. Generally, people with a steady affective partnership, due to the low perception of risk $^{(37)}$, use condoms less frequently during sexual intercourse, which makes them vulnerable to $\mathrm{HIV}^{(40)}$ and to late diagnosis.

The increase in schooling associated with a lower chance for later diagnosis was also evidenced in other studies ${ }^{(26,29,38,41-42)}$. This direct relationship between low schooling and increased risk for LD is probably due to greater difficulty in the access to information on means of prevention and on the diagnosis, and to the consequent low level of knowledge about HIV/AIDS. A research study carried out in Ethiopia showed an association between educational status and knowledge about HIV/AIDS with the delay in diagnosing the infection. Having a college degree decreased the likelihood of people being tested late, and those with a high level of knowledge were $74 \%$ less likely to be diagnosed late, when compared to those with a low level of knowledge(42).

The motivation for HIV screening and the frequency of testing after sexual intercourse with a steady partner were associated with the occurrence of the infection LD. Those individuals who were motivated to take the test for feeling sick, and those who took the test occasionally, almost never or never had a better chance of being diagnosed late. Periodic screening for the virus is related to people's perception of the health-disease process and of their vulnerability to HIV, as well as to their access to the health services that offer the test ${ }^{(39,42)}$.

The fact that the main motivation for taking the test was feeling sick, among those who were diagnosed later, reveals that the conceptions that people build throughout life, about their health and illness, influence their actions to guarantee their own well-being. It can be said that people diagnosed with more delay are generally those who adopt health practices that are strictly aimed at curing their illnesses, which does not exclude the influence of access barriers, including for performing the test. These individuals have problems with access to cultural goods and social development, with no possibility of reconstructing ways of thinking and acting in relation to effective prevention in order not to get sick ${ }^{(43)}$.

A number of research studies show that people do not consider having an HIV test because they are apparently healthy ${ }^{(38,42)}$. In Brazil, as the epidemic is concentrated, people are referred for HIV screening usually only when they have symptoms suggestive of infection or when they exhibit certain behaviors that increase the risk of transmitting the virus. Thus, screening moves away from a risk-focused strategy, as it disregards those individuals who do not openly express attitudes that are generally associated with an increased risk of contamination ${ }^{(26)}$.

Therefore, recommendations are proposed to change the panorama of the LD of HIV infection in Brazil, such as: expanding the offer of HIV testing to all Family Health Units and encouraging annual screening of the virus for all people who have unprotected sex; discussing the problem of the LD of HIV infection in academic spaces, in an interdisciplinary way, aiming at the formulation of new coping strategies; and fostering the scientific production on the subject in the country, which still requires more studies focused on the different realities of the states and the regions.

As limitations of the research, the following are pointed out: the inexistence or deficiency of data registration in some medical records regarding the LTCD4+ count and viral load at the time of diagnosis, the dates of diagnosis of HIV infection and of ART onset, and the presence of an AIDS indicative disease at the time of diagnosis. However, a $10 \%$ loss was foreseen in the sample calculation; therefore, these difficulties in obtaining the data did not compromise the reliability of the findings.

\section{Conclusion}

The high occurrence of late diagnosis for this infection is predominantly associated with sociodemographic and sexual aspects, without disregarding factors related to access to the health services. The likelihood of a later diagnosis is greater as age increases, among people who have a steady partnership and lower schooling, in individuals who sought the health service to perform the HIV test because they felt sick, and among those who never or almost never performed the quick test after an unprotected sexual intercourse with a steady partner.

It should be noted that the analysis was carried out in a broad and in-depth manner with primary sources of investigation, addressing, in addition to sociodemographic variables, factors related to sexuality and access to the health services, which strengthens the reliability and relevance of the findings. The submitted results are expected to contribute to the design of new strategies and policies aimed at the timely diagnosis of the infection. To expand the investigation of this problem, it is suggested that new research studies be carried out, from the perspective of health professionals and managers at all levels of care in the Unified Health System. 


\section{Acknowledgments}

To Anna Karolina Bezerra da Silva, Francisca Kelle de Sousa Ferreira and João Paulo Franco de Azevedo for their collaboration in the data collection phase. To Prof. Jorge Gustavo Velásquez Meléndez for his guidelines for the statistical data analysis.

\section{References}

1. Benzaken AS, Pereira GFM, Costa L, Tanuri A, Santos $A F$, Soares MA. Antiretroviral treatment, government policy and economy of HIV/AIDS in Brazil: is it time for HIV cure in the country?. AIDS Res Ther. 2019;16(19). doi: https://doi.org/10.1186/s12981-019-0234-2

2. Pereira GFM, Sabidó M, Caruso A, Benzaken AS. Decline in reported AIDS cases in Brazil after implementation of the test and treat initiative. BMC Infect Dis. 2019;19(579). doi: https://doi.org/10.1186/s12879-019-4018-z

3. Fauci AS. An HIV Vaccine: Mapping Uncharted Territory. JAMA. 2016;316(2):143-4. doi: 10.1001/jama.2016.7538

4. Dutra BS, Lédo AP, Lins-Kusterer L, Luz E, Prieto IR, Brites

C. Changes health-related quality of life in HIV-infected patients following initiation of antiretroviral therapy: a longitudinal study. Braz J Infect Dis. 2019;23(4):211-7. doi: https://doi.org/10.1016/j.bjid.2019.06.005

5. Mangal TD, Meireles MV, Pascom, ARP, Coelho RA, Benzaken AS, Hallett TB. Determinants of survival of people living with HIV/AIDS on antiretroviral therapy in Brazil 2006-2015. BMC Infect Dis. 2019;19(206). doi: https://doi.org/10.1186/s12879-019-3844-3

6. Montaner JS, Lima VD, Harrigan PR, Lourenço L, Yip B, Nosyk B, et al. Expansion of HAART coverage is associated with sustained decreases in HIV/AIDS morbidity, mortality and HIV transmission: the "HIV Treatment as Prevention" experience in a Canadian setting. PloS One. 2014;9(2):e87872. doi: 10.1371/ journal.pone.0087872

7. World Health Organization. Global Health Sector Strategy on HIV/AIDS 2016-2021 [Internet]. Geneva: WHO; 2016 [cited Nov 19, 2017]. Available from: https:// apps.who.int/iris/bitstream/handle/10665/246178/WHOHIV-2016.05-eng.pdf; jsessionid $=690078$ A6A208BB1282 86699E87CE4168? sequence $=1$.

8. Unaids. Ending AIDS: Progress towards the 90-90-90 targets. [Internet]. 2017 [cited Nov 13, 2017]. Available from: http://www.unaids.org/sites/default/files/media_ asset/Global_AIDS_update_2017_en.pdf

9. Dai SY, Liu JJ, Fan YG, Shan GS, Zhang HB, Li MQ, et al. Prevalence and factors associated with late HIV diagnosis. J Med Virol. [Internet]. 2015 [cited Oct 1, 2016];87(6):970-77. Available from: http://onlinelibrary. wiley.com/wol1/doi/10.1002/jmv.24066/full
10. Antinori A, Johnson M, Moreno S, Yazdanpanah Y, Rockstroh JK. Report of a European Working Group on late presentation with HIV infection: recommendations and regional variation. Antivir Ther. [Internet]. 2010 [cited Aug 20, 2016];15(Suppl 1):31-5. Available from: <http://www.intmedpress.com/journals/avt/article. $\mathrm{cfm}$ ?id $=1525 \&$ pid $=88 \&$ sType $=$ AVT $>$

11. Loreto S, Azevedo-Pereira JM. A infecção por HIV - importância das fases iniciais e do diagnóstico precoce. Acta Farm Port. [Internet]. 2012 [Acesso 20 ago 2016];1(2):5-17. Disponível em: http://www. actafarmaceuticaportuguesa.com/index.php/afp/article/ view/18.

12. Hall HI, Halverson J, Wilson DP, Suligoi B, Diez M, Le $\mathrm{Vu} S$, et al. Late diagnosis and entry to care after diagnosis of human immunodeficiency virus infection: a country comparison. PloS One. 2013;8(11):e77763. doi: 10.1371/journal.pone.0077763

13. Ministério da Saúde (BR). Departamento de Vigilância, Prevenção e Controle das Infecções Sexualmente Transmissíveis, do HIV/Aids e das Hepatites Virais. Relatório de Monitoramento Clínico do HIV. [Internet]. Brasília: Ministério da Saúde; 2018 [Acesso 20 jan 2019]. Disponível em: http://www.aids.gov.br/pt-br/pub/2018/ relatorio-de-monitoramento-clinico-do-hiv-2018

14. Grangeiro A, Escuder MM, Menezes PR, Alencar R, Ayres de Castilho E. Late Entry into HIV Care: Estimated Impact on AIDS Mortality Rates in Brazil, 2003-2006. PLoS One. 2011;6(1):e14585. doi: https://doi.org/10.1371/ journal.pone.0014585

15. Late presenters working group in COHERE in EuroCoord, Mocroft A1, Lundgren J, Antinori A, Monforte Ad, Brännström J, et al. Late presentation for HIV care across Europe: update from the Collaboration of Observational HIV Epidemiological Research Europe (COHERE) study, 2010 to 2013. Euro Surveill. 2015;20(47): pii=30070. doi: https://doi.org/10.2807/1560-7917.ES.2015.20.47.30070 16. Ministério da Saúde (BR). Secretaria de Vigilância em Saúde. Departamento de DST, AIDS e Hepatites Virais. Protocolo Clínico e Diretrizes Terapêuticas para Manejo da Infecção pelo HIV em Adultos. [Internet]. Brasília: Ministério da Saúde; 2018 [Acesso 15 jun 2019]. Disponível em: http://www.aids.gov.br/pt-br/pub/2013/ protocolo-clinico-e-diretrizes-terapeuticas-para-manejoda-infeccao-pelo-hiv-em-adultos

17. Ministério da Saúde (BR). Secretaria de Vigilância em Saúde. Boletim Epidemiológico HIV-AIDS. [Internet]. Brasília: Ministério da Saúde; 2019 [Acesso 15 mar 2020]. Disponível em: http://www.aids.gov.br/pt-br/pub/2019/ boletim-epidemiologico-de-hivaids-2019

18. Ministério da Saúde (BR). Secretaria de Vigilância em Saúde. Departamento de DST, AIDS e Hepatites Virais. Boletim Epidemiológico HIV-AIDS. [Internet]. 
Brasília: Ministério da Saúde; 2015 [Acesso 20 jun 2018]. Disponível em: http://www.aids.gov.br/pt-br/pub/2015/ boletim-epidemiologico-hivaids-2015

19. Antinori A, Coenen T, Costagiola D, Dedes N, Ellefson M, Gatell J, et al. Late presentation of HIV infection: a consensus definition. HIV Med. 2011;12(1):61-4. doi: https://doi.org/10.1111/j.1468-1293.2010.00857.x 20. Abreu MNS, Siqueira AL, Caiaffa WT. Ordinal logistic regression in epidemiological studies. Rev Saude Publ. [Internet]. 2009 [cited Nov 21, 2017];43(1):183-94. Available from: http://www.scielo.br/scielo. php?script=sci_arttext\&pid $=$ S0034891020090001000 25\&lng=en\&nrm=iso. doi: http://dx.doi.org/10.1590/ S0034-89102009000100025

21. Assen A, Molla F, Wondimu A, Abrha S, Melkam $W$, Tadesse $E$, et al. Late presentation for diagnosis of HIV infection among HIV positive patients in South Tigray Zone, Ethiopia. BMC Public Health. 2016;16:558. doi: 10.1186/s12889-016-3263-y

22. Magis-Rodríguez CL, Villafuerte-García A, Cruz-Flores RA, Uribe-Zúñiga P. Inicio tardío de terapia antirretroviral en México. Salud Publica Mex. [Internet]. 2015 [Acceso 14 mar 2020];57(Suppl 2):s127-34. Disponible en: http:// www.scielo.org.mx/scielo.php?script=sci_arttext\&pid=S $003636342015000800006 \&$ Ing $=p t$

23. Dourado I, MacCarthy S, Lima C, Veras MA, Kerr L, Brito AM, et al. What's pregnancy got to do with it? Late presentation to HIV/AIDS services in Northeastern Brazil. AIDS Care. 2014;26(12):1514-20. doi: $10.1080 / 09540121.2014 .938016$

24. Valentini MB, Toledo MLG, Fonseca MO, Thiersch LMS, Toledo ISB, Machado FC], et al. Evaluation of late presentation for HIV treatment in a reference center in Belo Horizonte, Southeastern Brazil, from 2008 to 2010. Braz J Infect Dis. [Internet]. 2015 June [cited Nov 4, 2019];19(3):253-62. Available from: http://www.scielo. br/scielo.php?script=sci_arttext\&pid=S14138670201500 0300253\&lng=en

25. MacCarthy S, Brignol S, Reddy M, Nunn A, Dourado I. Late presentation to HIV/AIDS care in Brazil among men who self-identify as heterosexual. Rev Saude Publ. 2016;50:54. doi: https://doi.org/10.1590/S15188787.2016050006352

26. MacCarthy S, Hoffmann M, Nunn A, Silva LAVD, Dourado I. Barriers to HIV testing, linkage to care, and treatment adherence: a cross-sectional study from a large urban center of Brazil. Rev Panam Salud Publ. [Internet]. 2016 [cited Apr 18, 2018];40:418-26. Available from: http://iris.paho.org/xmlui/handle/123456789/33661

27. Piñeirúa A, Sierra-Madero J, Cahn P, Palmero RNG, Buitrago EM, Young B, et al. The HIV care continuum in Latin America: challenges and opportunities. Lancet Infect
Dis.2015;15(7):833-9. doi: http://dx.doi.org/10.1016/ S1473-3099(15)00108-5

28. Guaraldi G, Zona S, Menozzi M, Brothers TD, Carli F, Stentarelli $C$, et al. Late presentation increases risk and costs of non-infectious comorbidities in people with HIV: an Italian cost impact study. AIDS Res Ther. 2017;14(1):8. doi: 10.1186/s12981-016-0129-4

29. Sobrino-Vegas $P$, Moreno $S$, Rubio R, Viciana $P$, Bernardino JI, Blanco JR, et al. Impact of late presentation of HIV infection on short-, mid-and long-term mortality and causes of death in a multicenter national cohort: 2004-2013. J Infect. 2016;72(5):587-96. doi: https:// doi.org/10.1016/j.jinf.2016.01.017

30. Komninakis SV, Mota ML, Hunter JR, Diaz RS. Late presentation HIV/AIDS is still a challenge in Brazil and worldwide. AIDS Res Hum Retroviruses. 2018;34(2):129-31. doi: https://doi.org/10.1089/aid.2015.0379

31. Moreira RI, Luz PM, Struchiner CJ, Morgado M, Veloso VG, Keruly JC, et al. Immune status at presentation for HIV clinical care in Rio de Janeiro and Baltimore. J Acquir Immune Defic Syndr. 2011 Aug;57(Suppl 3):S171-8. doi: 10.1097/QAI.0b013e31821e9d59

32. Hu, X, Liang, B, Zhou, C, Junjun J, Jiegang $H$, Chuanyi $\mathrm{N}$, et al. HIV late presentation and advanced HIV disease among patients with newly diagnosed HIV/AIDS in Southwestern China: a large-scale cross-sectional study. AIDS Res Ther. 2019;16(6). doi: https://doi.org/10.1186/ s12981-019-0221-7

33. Tavoschi L, Gomes Dias J, Pharris A, Network EEHS. New HIV diagnoses among adults aged 50 years or older in 31 European countries, 2004-15: an analysis of surveillance data. Lancet HIV. 2017;4(11):e514-21. doi: https://doi.org/10.1016/S2352-3018(17)30155-8 34. Jeong SJ, Italiano C, Chaiwarith R, Ng OT, Vanar S, Jiamsakul $A$, et al. Late presentation into care of HIV disease and its associated factors in Asia: results of TAHOD. AIDS Res Hum Retroviruses. 2016;32(3):255-61. doi: http://doi.org/10.1089/aid.2015.0058

35. Oltramari LC, Camargo BV. AIDS, conjugal relations and reliance: a study on socials representation. Psicol Estud. [Internet]. 2010 [cited Out 16, 2017];15(2):275-83. Available from: http://www.scielo.br/scielo.php?script=sci_ arttext\&pid=S141373722010000200006. doi: http:// dx.doi.org/10.1590/S1413-73722010000200006

36. Arraes CDO, Palos MAP, Barbosa MA, Teles SA, Souza MMD, Matos MAD. Masculinity, vulnerability and prevention of STD/HIV/AIDS among male adolescents: social representations in a land reform settlement. Rev. Latino-Am Enfermagem. 2013;21(6):1266-73. doi: 10.1590/0104-1169.3059.2363

37. Karaosmanoğlu HK, Mete B, Gündüz A, Aydin ÖA, Sargin $F$, Sevgi DY, et al. Late presentation among patients with human immunodeficiency virus infection 
in Turkey. Cent Eur J Public Health. 2019;27(3):229-34. doi: 10.21101/cejph.a5416. PubMed PMID: 31580559

38. Hachfeld A, Ledergerber B, Darling K, Weber R, Calmy A, Battegay $M$, et al. Reasons for late presentation to HIV care in Switzerland. J Int AIDS Soc. 2015;18(1):20317. doi: https://doi.org/10.7448/IAS.18.1.20317

39. Fuster-RuizdeApodaca MJ, Laguia A, Molero F, Toledo J, Arrillaga A, Jaen A. Psychosocial determinants of HIV testing across stages of change in Spanish population: a cross-sectional national survey. BMC Public Health. 2017;17(1):234. doi: 10.1186/s12889-017-4148-4

40. Sperhacke RD, Motta LR, Kato SK, Vanni AC, Paganella MP, Oliveira MCP, et al. HIV prevalence and sexual behavior among young male conscripts in the Brazilian army, 2016. Medicine (Baltimore). 2018 May;97(1S Suppl 1):S25-S31. doi: 10.1097/MD.0000000000009014. PMID: 29794600; PMCID: PMC5991542

41. Trepka MJ, Fennie KP, Sheehan DM, Lutfi K, Maddox L, Spencer Lieb. Late HIV diagnosis: Differences by rural/urban residence, Florida, 2007-2011. AIDS patient care and STDs. 2014;28(4):188-97. doi: http://doi. org/10.1089/apc.2013.0362

42. Beyene MB, Beyene HB. Predictors of Late HIV Diagnosis among Adult People Living with HIV/AIDS Who Undertake an Initial CD4 T Cell Evaluation, Northern Ethiopia: A Case-Control Study. PLoS One. 2015;10(10):e0140004. doi: https://doi.org/10.1371/journal.pone.0140004

43. Ribeiro LCS, Giami A, Freitas MIF. Representations of people living with HIV: influences on the late diagnosis of infection. Rev Esc Enferm USP. 2019;53:e03439. doi: http://dx.doi.org/10.1590/S1980-220X2018009703439 Creative Commons (CC BY).

This license lets others distribute, remix, tweak, and build upon your work, even commercially, as long as they credit you for the original creation. This is the most accommodating of licenses offered. Recommended for maximum dissemination and use of licensed materials. 